\title{
The Effectiveness of Communication Styles in the Application of E-Learning During the Covid-19 Pandemic
}

\author{
Dedi Rianto Rahadi ${ }^{\mathrm{a}, 1^{*}}$, Mira Yuniar ${ }^{\mathrm{b}, 2}$ \\ a,bPresident University \\ Email: ${ }^{1}$ Dedi1968@yahoo.com; ${ }^{2}$ Mira.yuniar@student.president.ac.id \\ *corresponding author
}

\author{
Keywords: \\ Effectiveness of communication, \\ e-learning, students, and lecturers
}

\begin{abstract}
The period of the Covid-19 pandemic requires the education sector to adapt to the learning process carried out online. The adaptation that must be doneins delivering material that is carried out interactively using communication media. In this learning process, indirectly, changes become a new challenge for teachers and students, in this case, lecturers and students. This study aimed to determine the effectiveness of communication styles in using e-learning during the Covid-19 pandemic. The research method used is descriptive quantitative and data collection through survey methods conducted online via google form with research questions using a Likert scale. Communication can be effective if the recipient of the message can receive good information from the sender of the message. The results showed that the lecturer had used a communication style following the wishes and obtained positive interactions from students. Because, when the online learning process, there is two-way communication between the recipient (student) and the message sender (lecturer), so that students can understand the material described. The assertive communication style approach can be used to solve problems in the online learning process.
\end{abstract}

Copyright (C) 2021 Channel Jurnal Komunikasi. All right reserved.

\section{INTRODUCTION}

The online learning system is a policy set by several local governments. The policy is determined by the Decree of the Minister of Education and Culture of the Republic of Indonesia in connection with Letter No. 4 of 2020, concerning the implementation of education policies in emergencies before the spread of the Covid-19 virus. The policy for online learning activities (e-learning) takes place for all levels of education, and the learning process changes (Jailani, Sutrisno $\&$ Siddik, 2020). The corona pandemic requires us to adapt to the learning process in a new way and atmosphere. In this case, we need to make adjustments to online learning. The adjustment that must be made is the delivery of interactive online material. That is, learning participants use electronic media that are connected to the network as a learning medium.

This change is a new challenge for both lecturers and students. The learning process indirectly changes the way of communicating. Before learning is carried out online, students can meet directly with the lecturer and communicate directly (face-to-face). Nevertheless, because of this virus, if people want to communicate related to the material that has been studied, sometimes it cannot be expressed in person because lecturers do not always sit at the laptop and always look at the communication device or network problems. Besides, in the online learning process, students sometimes lack understanding of the material that has been explained (Wowor \& Putri, 2021).

In learning activities, the media used to carry out online learning uses video communication applications, Google Meet or Zoom Meeting. They are utilizing this technology to carry out distance learning. It is essential and valuable to keep building communication. This interactive communication between students and lecturers must be based on a communication style to carry out a communication process that can be said to be effective.

In general, effectiveness is the achievement of learning objectives that the individual has determined in the learning process (Müller et al., 2018). This statement is supported by theory (Nguyen, 2015) which states that effectiveness can be seen from students' interest in the learning process. In the learning process, the communication style used by lecturers is fundamental to increasing student interest in learning. This fact is supported by Leonardi's (2014) theory which states that in the communication process, there are many possible consequences of how it is applied in the next few years. 
It is a challenge for students to be able to adapt in facing online learning activities. Students are also required to be able to provide feedback and understand the material optimally. Feedback is given such as responses, questions and can answer questions related to the material that has been described. This study aimed to determine the effectiveness of communication styles in using e-learning during the Covid-19 pandemic. So that lecturers and students can build effective communication and online learning activities during this pandemic can be carried out correctly.

Online-based learning in a learning process shows that the lecturer's responsibility must produce a reaction or reciprocity in the learning process (Hoq, 2020). In research, Wowor \& Putri (2021) said that it is essential that students and lecturers build communication with each other so that the learning process can be effective. Therefore, the authors are interested in developing this research to describe a communication style in the online learning process that can be effective. The formulation of this research problem is what kind of effectiveness of the communication style lecturers use in online learning activities during the Covid-19 pandemic.

\section{LITERATURE REVIEW}

Etymological communication comes from the Latin "Communicare," which means "spread" through semiotic rules, signs, and symbols implemented together with other groups. It can be said that, as a social being, communication has the most critical part of human life. With communication, humans can be called to each other and close relationships among social creatures (Ruben \& Stewart (2006).

Therefore, communication is a process by which a person, group, and organization create and uses the information to establish relationships with other people, which is done verbally. Communication in the learning process is where lecturers build effective relationships or relationships with students (Iriantara \& Syaripudin, 2013). Effective communication is related to the message sender and the message recipient.

If the message recipient can understand the meaning of the message sent by the lecturer, then the communication can be said to be effective (Fajriyah, 2019). Whether interpersonal communication is effective or not can be seen from the excellent feedback between the sender and the message recipient. Reciprocity can take the form of statements, actions, and attitudes. Meaning that students can capture messages or information conveyed by lecturers following the objectives of the information, namely it is better to improve science and technology or change attitudes (Basori, 2017).

According to Wisman (2017), message senders (communicators), message recipients, and the media used to convey messages are essential for practical communication skills. In this case, the communication skills used by lecturers for students use video communication tools such as Google Meet, Zoom, or any other video conference software. Through good media, students will find it easier to apply the learning materials provided by the lecturer.

Communication style is the expertise of communicators in communicating verbally and non-verbally in their learning activities. She and Fisher (2002) categorize the pattern of communication styles in the learning process into five parts: first, Challenging is a communication style used by lecturers to interrogate students in the learning process to understand the material that has been stated. Second, encouragement and praise, namely the extent to which a lecturer encourages and motivates students to be even better in teaching and learning activities. Third, non-verbal support is how lecturers use positive body language communication with students. Fourth, Understanding and friendliness in this model are related to how lecturers understand and support students. Fifth, the Controlling model is related to how the lecturer controls and directs student behavior in the classroom.

\section{RESEARCH METHODS}

In this study, researchers used a descriptive method using a quantitative approach and a survey method conducted online through the google module (google form). Descriptive research uses surveys, observations, or interviews concerning using problems that concern us (Russeffendi, 2010). Sugiyono (2017) suggests a method in quantitative analysis to study a specific population or sample in research. Researchers used the survey method to collect stated (Sekaran \& Bougie, 2016)to collect information from several respondents to explain, compare, and explain their attitudes, behaviors, and knowledge.

This study focuses more on the observation method in a questionnaire with research questions using the Likert scale method. The Likert scale in this study has five (5) kinds of statements, value one (1) strongly disagrees, value two (2) disagrees, value three (3) is neutral, value four (4) is agreed, and value fives (5) strongly agree. The sample collection system used in this study is not a probability sample or a target sample. The selection is limited to specific standards and must provide the necessary information (Sekaran \& Bouigie, 2016). This research involved 30 active students of President University in Cikarang, West Java.

The author uses the Slovin formula for an error rate of 10\%, which is stated (Sekaran \& Bougie, 2016). The total population of the night class management program was 54 students, and the entire sample was 35 respondents. After tabulation, 35 respondents who filled in correctly were 30 respondents. The analysis technique used is a descriptive quantitative approach by giving the respondent 5 (five) questions. The list of questions was carried out by testing the 
construct validity, where the researcher asked for help from an expert opinion, namely the caregiver lecturer. The constructed instrument is based on communication theory and has been consulted with experts in the field. The table below obtain the results of the validity test:

Tabel 1. Validity Test

\begin{tabular}{lr}
\hline \multicolumn{2}{c}{ Item-Total Statistics } \\
\hline \multicolumn{3}{c}{$\begin{array}{c}\text { Corrected Item-Total } \\
\text { Correlation }\end{array}$} \\
\hline com1 & .315 \\
\hline com2 & .358 \\
\hline com3 & .463 \\
\hline com4 & .406 \\
\hline com5 & .396 \\
\hline
\end{tabular}

From the test results, it can be shown with a significant level of $5 \%$ with $\mathrm{N}$ amounting to 30 , where $\mathrm{r}$ count $>\mathrm{r}$ table 0.3061 that can be concluded that all the questions are valid.

\section{RESULT AND DISCUSSION}

This study uses several components that support the communication styles used in teaching and learning activities (She \& Fisher, 2002). First, Challenging is a pattern of communication styles used by lecturers in the learning process to test the extent of student understanding in the learning process. In this case, students can answer their language based on personal knowledge in teaching and learning activities with a particular difficulty level.

Table 2. Observation Results in Statement about Challenging's communication style

\begin{tabular}{llc}
\hline \multicolumn{1}{c}{ Challenging } & \multicolumn{1}{c}{ Statement } & Percentage \\
\cline { 2 - 3 } 1 = Strongly Disagree & $0,0 \%$ \\
$2=$ Disagree & $5,0 \%$ \\
\cline { 2 - 3 } $3=$ Neutral & $28,3 \%$ \\
$4=$ Agree & $45,0 \%$ \\
\hline $5=$ Strongly Agree & $21,7 \%$ \\
\hline
\end{tabular}

The results of the observation data above show that the average student chooses to agree with a percentage of 45.0 percent, which means that every lecturer who carries out student learning activities online has used a challenging communication style for students. It can be concluded, the learning method used by lecturers during online lectures is two-way communication. Two-way communication is an interaction between lecturers and students to measure the extent of student understanding in the learning process.

Table 3. Observation Results in Statement about Encouragement and Praise communication style

\begin{tabular}{llc}
\hline \multicolumn{1}{c}{ Encouragement and praise } & \multicolumn{1}{c}{ Statement } & Percentage \\
\cline { 2 - 3 } & $1=$ Strongly Disagree & $0,0 \%$ \\
2 = Disagree & $5,0 \%$ \\
\cline { 2 - 3 } $3=$ Neutral & $33,3 \%$ \\
$4=$ Agree & $45,0 \%$ \\
\cline { 2 - 3 } $5=$ Strongly Agree & $16,7 \%$ \\
\hline
\end{tabular}

Then the second, namely, the teaching-learning process with a communication style pattern of encouragement and praise. It can be seen from the table above and the average student chooses to agree with a total percentage of 45.0 percent. In student learning activities carried out online, lecturers use this communication style to encourage and encourage students to be even better in their learning process. 
Table 4. Observation Results in Statement about communication style Non-verbal support

\begin{tabular}{llc}
\hline \multicolumn{1}{c}{ Son-verbal support } & \multicolumn{1}{c}{ Sercentage } \\
\cline { 2 - 3 } 1 = Strongly Disagree & $0,0 \%$ \\
2 = Disagree & $0,0 \%$ \\
\cline { 2 - 3 } $3=$ Neutral & $30,0 \%$ \\
$4=$ Agree & $46,7 \%$ \\
\cline { 2 - 3 } $5=$ Strongly Agree & $23,3 \%$ \\
\hline
\end{tabular}

Third, the non-verbal support style of communication in the table above shows that the average student chooses a statement of agreement with a total percentage of 46.7 percent. Non-verbal communication is an interaction using body languages such as nodding the head, indicating that the message recipient understands the message sender's statement and the facial expression of the message recipient. In this case, non-verbal communication supports student learning activities conducted online by lecturers and students. It means that lecturers communicate positively through non-verbal communication when learning online activities through communication media such as Google meetings and Zoom meetings.

Table 5. Observation Results in Statement about Understanding and friendly communication style

\begin{tabular}{llc}
\hline Understanding and friendly & \multicolumn{1}{c}{ Statement } & Percentage \\
\cline { 2 - 3 } & 1 = Strongly Disagree & $0,0 \%$ \\
& $2=$ Disagree & $3,3 \%$ \\
\cline { 2 - 3 } $3=$ Neutral & $10,0 \%$ \\
$4=$ Agree & $51,7 \%$ \\
\cline { 2 - 3 } 5 = Strongly Agree & $35,0 \%$ \\
\hline
\end{tabular}

Fourth, this pattern understanding and friend communication style refers to how the lecturer understands and is friendly with students. The observation data above shows that the average student agrees exchange was with a total percentage of 51.7 percent. In student learning activities that are carried out online, the lecturer constantly monitors the students' movements, continuously checks the extent of student understanding, and is willing to explain the material that supports learning activities.

Tabel 6. Observation Results in Statement about the Controlling communication style

\begin{tabular}{llc}
\hline \multicolumn{1}{c}{ Controlling } & \multicolumn{1}{c}{ Statement } & Percentage \\
\cline { 2 - 3 } $1=$ Strongly Disagree & $0,0 \%$ \\
$2=$ Disagree & $0,0 \%$ \\
\cline { 2 - 3 } $3=$ Neutral & $1,7 \%$ \\
$4=$ Agree & $45,0 \%$ \\
\cline { 2 - 2 } & $5=$ Strongly Agree & $53,3 \%$ \\
\hline
\end{tabular}

The fifth is controlling communication style patterns, namely how lecturers own and manage student behavior in class. The observation data above shows that the average student chooses a statement that strongly agrees with a total percentage of 53.3 percent. Most lecturers control and manage student behavior to do assignments and follow the directions given when the online learning process is in progress.

Based on the validity test of each question item that has been consulted with experts, the results of the respondents' answers are as follows. In the communication process, it can be said that it is effective not only from sending the message and receiving the message. As previously described, Fajriyah (2019) argues that if the recipient of the message (student) can accept the intent of the letter sent by the sender of the message (lecturer), then the communication can be said to be effective. In other words, in this case, if students can respond well to the knowledge that the lecturer has conveyed, then students can be said to have communicated effectively in the online learning process. The interactions carried out are in the form of questions, responses, or giving each other opinions, which can open up space for discussion. So that students have the opportunity to ask questions or express their views, give positive responses, and provide answers following 
the material that has been explained. Besides, the interactions that take place in the learning process also offer positive feedback.

This result is supported by the theory described above. The feedback given by students means that they can capture messages or information conveyed by lecturers following the purpose of information (Basori, 2017). From the results of the observation data above, the five patterns of communication styles are the interaction between lecturers and students in the online learning process. The exchange was excellent and effective because the communication style applied by the lecturer has encouraged students to focus more on their online learning activities. The communication style used by the lecturer can also lead to reciprocal interactions with students. Therefore, it can be said that students capture messages or information conveyed by lecturers. So that students can still carry out their role as students well, even though learning is carried out online due to the government's implementation of learning from home.

From the description above, the effective communication style that can be applied in the online learning process during a pandemic is using an assertive communication style approach. Lecturers and students understand each other what they want to convey. The condition of the Covid-19 pandemic is not a shared desire, but this condition requires an online learning process. The assertive communication approach can help lecturers understand what students want and can comfortably convey material objectives.

\section{CONCLUSIONS AND SUGGESTIONS}

The implementation of learning from home by the government demands that all learning activities be carried out online. Therefore, both lecturers and students must adapt to their learning activities. If previously the learning process could be done face-to-face or in person, the learning process was carried out online during this pandemic. The learning process can still run by utilizing video communication media such as the Google Meeting and Zoom Meeting.

Based on the observation data, it shows that there are various communication methods. From the five patterns of communication styles applied by lecturers to students in the online learning process, it can be concluded that they are pretty good and practical. Because the sender of the message, in this case, is the lecturer who has used an appropriate communication style and has received positive responses from students. The application of communication styles in this learning activity can also increase students' understanding of the material is explained. So that students can receive or understand the material that has been presented.

Suggestions put forward for further researchers: they can add new indicators such as behavior and environment in the research object so that communication can run according to the online learning objective. Increasing the number of respondents will give maximum results. The time and place in the research subject may vary with certain conditions and circumstances.

\section{REFERENCES}

[1] Basori. (2017). Efektifitas Komunikasi Pembelajaran Online Dengan Menggunakan Media E-Learning Pada Perkuliahan Body Otomotif. Jurnal Ilmiah Pendidikan Teknik dan Kejuruan, 7(2).

[2] Müller, C., Stahl, M., Alder, M. \& Müller, M. (2018). Learning Effectiveness and Students' Perceptions in A Flexible Learning Course. European Journal of Open, Distance and E-Learning,21(2) 44-52. https://doi.org/10.2478/ eurodl-2018-0006

[3] Ruben, B.D. \& Stewart, L.P. (2006). Communication and Human Behavior. United States: Allyn and Bacon.

[4] Fajriyah, N. R. (2019). Efektivitas Komunikasi Organisasi Dalam Manajemen Program Kerja Pos Yandu . Jurnal InterAct, 8(1).

[5] Hoq, M. Z. (2020). E-Learning During the Period of Pandemic (COVID-19) in the Kingdom of Saudi Arabia: An Empirical Study. American Journal of Educational Research, 457-464.

[6] Iriantara, Y., \& Syaripudin, U. (2013). Komunikasi Pendidikan. Bandung: Simbiosa Rekatama Media.

[7] Jailani, M. S., Sutrisno, \& Siddik, M. M. (2020). The Impact of Online Learning Policy during the Covid-19 Pandemic: An Analysis of Islamic Education. Innovation: Journal for Religious-Innovations Studies, 151-166.

[8] Mutawakil, \& Nuraedah. (2019). Gaya Komunikasi Dosen dalam Pebmbelajaran Mahasiswa. Communicatus: Jurnal Ilmu Komunikasi, 135-153.

[9] Russeffendi, E. (2010). Dasar-Dasar Penelitian Pendidikan dan Bidang Non-Eksakta Lainnya. Bandung: Tarsito.

[10] Sekaran, U., \& Bougie, R. (2016). Research Methods for Business (Seventh Ed). John Wiley \& Sons.

[11] Sendjaja, S. D. (2005). Teori Komunikasi. Jakarta: Pusat Penerbitan Universitas Terbuka.

[12] She, H. C., \& Fisher, D. (2002). Teacher Communication Behavior and its Association With Students'. Journal of Research in Science Teaching, 63-78. 
[13] Suciati, P., Maulidiyanti, M., Triawinata, F. M., \& Rizkiyanti, N. (2018). Pengaruh Gaya Komunikasi Dosen Dalam Proses Pembelajaran Terhadap Motivasi Belajar Mahasiswa HUMAS Program Pendidikan Vokasi. Jurnal Social Humaniora Terapan, 15-20.

[14] Sugiyono. (2017). Metode Penelitian Kuantitatif, Kualitatif, dan R\&D. Bandung: Alfabeta, CV.

[15] Nguyen, T. (2015). The effectiveness of online learning: beyondno significant difference and future horizons. MERLOT Journal of Online Learning and Teaching, 11(2), 309-319.

[16] Usman, M. R. (2019). Efektivitas Pembelajaran Matematika Melalui Penerapan Model MEA (Means-EndsAnalysis) pada siswa SMP. Jurnal Majamath, 2(1).

[17] Wisman, Y. (2016). Dinamika Komunikasi. CV Pustaka Setia.

[18] Wowor, H. A., \& Putri, K. Y. (2021). Efektivitas Komunikasi dalam Perkuliahan Online terhadap Proses Belajar pada Mahasiswa Manokwari Papua Barat. Jurnal Komunikasi Pendidikan, 79-92.

[19] Yahya, S. D., \& Yulianto, H. (2018). Burnout Sebagai Implikasi Peran Ganda (Pekerjaan-Kuliah) pada Mahasiswa yang Bekerja di Kota Makassar. AKMEN Jurnal Ilmiah, 564-573. 